\title{
Future trends in social media use for strategic organisation communication: Results of a Delphi study
}

\author{
ANNE LINKE \\ University of Leipzig, Germany \\ ANSGAR ZERFASS \\ University of Leipzig, Germany
}

\begin{abstract}
This article examines current uses of social media for communication by enterprises, political organisations and non-profit organisations (NPOs) and identifies likely future trends. Based on a quantitative online survey among 860 communication professionals in Germany and a follow-up qualitative Delphi study with 32 identified experts from the organisational communication profession and academia, it explores the status quo and aims to identify future directions. While organisations show more advanced structures for social media communication compared to earlier research findings, the empirical data also identifies many shortcomings. The potentials of social media communication are not fully exploited due to missing prerequisites including governance structures, rules and resources. Looking into the future, the Delphi panel suggests that dedicated budgets, social media guidelines and other structural aspects will increase in the near future. However, many organisations will find specific ways to deal with the issue and common strategies are rare. At the same time, according to the qualitative findings, social media evaluation and cooperation across the boundaries of departments and organisational functions are likely to stay underdeveloped.
\end{abstract}

\section{Introduction}

Social media have become an important communication platform in many organisations. When social media first emerged around the turn of the millennium, many merely experimented with the new technologies. Participating in and profiting from the new technological developments was the major aim. Early research (Fraser \& Dutta, 2008; Kaplan \& Haenlein, 2010; Li \& Bernoff, 2008; Vaughan \& Tinker, 2009) criticised this. It was suggested that the focus should be on developing strategies and overarching structures that enable the use of social media in communication. This call has been heard, at least in Germany, where the majority of corporations, political organisations and Non Profit Organisations (NPOs) have since moved beyond the experimental stage (BITKOM, 2012; Fink, Zerfass, \& Linke, 2011).

However, new technologies as well as the communication landscape are constantly changing, which means that social media communication in the future is unlikely to remain static. Some authors created prognoses about future developments, ranging from the extinction of certain applications like Facebook to digital utopias (e.g. Castells, 2010; Jenkins, 2006; Safko, 2010). While most prognoses describe a positive picture, empirical data and longitudinal studies to date show that the integration of social media into existing structures and processes has taken much longer than expected (Fink et al., 2011; Macnamara \& Zerfass, 2012; Wright \& Hinson, 2011; Zerfass et al., 2012). This questions the validity of many forecasts, which have mostly focused on very specific aspects or are based on poor and unreliable data, including individual impressions by authors from their everyday practical experience. Trends can easily 
be overlooked by leaving out important influencing factors or by vaguely extrapolating from past data to future developments. As the development of social media has been very dynamic, such approaches are particularly problematic. Furthermore, individual prognoses can be more or less consciously biased by author's own specific perspectives and underlying intentions.

This article shows an alternative way to improve knowledge about future developments in social media communication. The study 'Social Media Delphi 2012' combines quantitative survey research with a qualitative two-wave Delphi study to identify the current status and to discuss the probability and time frame for advancements in the practice of strategic communication.

\section{Literature Review}

\section{Definitions of web 2.0 and social media}

The definitions of web 2.0 and social media are incongruently used in the professional and academic literature, and even more so in everyday conversations. In order to avoid misunderstandings, this article utilises Kaplan and Haenlein's (2010, p. 61), definition of social media as "a group of Internet-based applications that build on the ideological and technological foundations of Web 2.0, and that allow the creation and exchange of User Generated Content.” This implies a clear distinction between technological, economic and judicial phenomena encompassed within the Web 2.0 on the one hand and applied social media on the other. While the term "new media" is also often used in this context, it will be rejected for this article as it fails to highlight the social and interactive nature behind the technologies. The boundaries between old and new media blur, particularly when it comes to the presentation of newspapers or TV programs on social web platforms. Moreover, some social media applications have been around for more than a decade whilst its most prominent platforms, Facebook and YouTube, have been in operation since 2004 and 2006 respectively. Although these platforms can still be considered 'new' in a technological sense, the passage of time will see new media today becoming an established part of the landscape and newer forms of media assuming the 'new media' mantle (see e.g. Brown \& Duguid, 2000).

O'Reilly (2005) describes the realm of Web 2.0 by naming six trends: programs become platforms; wisdom of crowds; data inside; customer integration/user-based content; ubiquitous and dynamic conditions; and browser-independent content. To this end, social media, when compared to earlier web applications, stands out for allowing a rapid mass creation and interactive exchange of user-generated content (see e.g. Contractor \& Eisenberg, 1990; Hippner, 2006). Previously, the internet contained a static collection of documents and was a "mostly read-only web" for the majority of users. In the age of Web 2.0, the communication landscape is constantly changing through user generated content, which is collaboratively created and assessed by a high number of interlinked social media users. Hence, the Web 2.0 offers a wide variety of possibilities to contribute content and to create collective intelligence (Argenti \& Barnes, 2009). Some authors view this change as so important that they name it a "digital (r)evolution" (Macnamara 2010a) or a paradigm shift (Döbler, 2008).

\section{The use of social media for strategic communication}

In recent years, the usage of social media has steadily increased (see e.g. Nielsen, 2012) and the biggest social media platforms like Facebook and YouTube have become powerful brands (Postman, 2009, p. VII). Consequently, an increasing number of organisations are using social media communication (Young et al., 2008). Many authors have written about the positive impacts of social media for organisational communication (Bauer, 2007; Holtz et al., 
2008; Pleil \& Zerfass, 2007; Ruisinger, 2007). The ease and speed with which information can be accessed, the capacity to engage with stakeholders, the richer experiences for users, and improved web metrics are just a few of the benefits that have encouraged many corporations to employ social media communication (Postman, 2009; Lattemann \& Stieglitz, 2007; Macnamara, 2010b). Some 46 percent of European communication professionals believe that coping with the digital evolution and the social web is currently the most important strategic issue and will remain so for the next three years (Zerfass et al., 2012, p. 53-55). In other words, communication professionals have to adapt: "If you don't embrace PR 2.0 or you don't act with urgency, your lack of engagement is a disservice to your brand ... The public wants Social Media. They don't accept anything less. Your job is to know and deliver the needed communication” (Breakenridge, 2008, p. 187).

However, a variety of challenges have to be addressed because social media have "brought about profound changes in the nature and organisation of contemporary communication" (Nightingale \& Dwyer, 2007, p. 1). As the social web alters communication between individuals and organisations (see e.g. Balnaves, Donald, \& Shoesmith, 2008), Pavlik calls for consideration of not only the impact of social media on communication measures and styles, but also the "implications of technology on organisational structure, culture and management” (Pavlik, 2007, p. 3). Traditional organisation-centred thinking is becoming outdated, as interactions become more complex within multiple new and ever-changing communication arenas (Luoma-aho \& Vos, 2010). The new technologies offer organisations new opportunities to present their viewpoints directly to key constituents, but at the same time they tend to lose control over the dissemination of information (Ihator 2001). Hence, corporations have to decide whether or not to take on the risk. Participants in the European Communication Monitor 2010 survey identified the fact that everyone within an organisation can spread information as being especially risky (Zerfass et al., 2010, p. 83). On the whole, the loss of control and the increased amount of work are considered the most challenging tasks when using social media for strategic communication (Fink \& Zerfass, 2010).

In order to overcome these obstacles, many organisations have started to invest in governance structures, including social media strategies, policies and guidelines (Barnes \& Mattson, 2009; Fink et al., 2011). Also, several studies show that more and more think about how to assign responsibilities for social media communication within the organisation (Diga \& Kelleher, 2009; Toledano, 2010; Stankovic-Rice, 2011). According to the Altimeter Survey of Corporate Social Strategists (Owyang \& Li, 2011), different ways of prioritising social business budgets have been developed. These developments mark a first step towards establishing social media communication in organisational settings. But what will the future bring regarding this topic?

\section{Research questions and methodology}

Presently, there is little empirical research that looks at the future development of structures for social media communication in organisations. Most studies focus on past developments or the status quo, and examine particular social media activities rather than the broader context. The research project reported here explores and maps expected future trends regarding the development of necessary rules and resources for social media communication. In order to identify change, the studies firstly established the status quo of strategic social media communication in a sample of German organisations. Then, expectations in relation to social media use over the coming years were explored with the help of Delphi interviews. Therefore, two basic questions guide the research: How is social media communication 
strategically applied in German organisations? And, how will it develop in the future? Based on this, more specific research questions were derived as follows:

RQ1: To what extent are rules and resources for social media communication established in German organisations, and how will this develop in the future?

RQ2: How are processes and responsibilities for social media communication assigned to various functions in German organisations, and how will this develop in the future?

RQ3: To what extent are budgets allocated for social media communication in German organisations, and how will this develop in the future?

RQ4: How is social media communication evaluated in German organisations, and how will this develop in the future?

A multi-method approach was used to answer these research questions. In the first stage, a quantitative online survey was conducted among professionals working in communication departments in Germany in April and May 2012. The sample comprised 860 communicators from listed (14.7 percent) and unlisted companies (48.1 percent), governmental institutions and associations (22.7 percent), and non-profit organisations (14.5 percent), including 30.2 percent with managerial responsibilities. Employees in agencies, consultants, students, and other participants were excluded from the sample. A structured survey questionnaire with 27 questions was conducted and stored online. The participants received a personal invitation to participate as well as a reminder via a mailing list provided by the magazine Pressesprecher and the Bundesverband deutscher Pressesprecher (BdP). Four thousand communication professionals were contacted, resulting in 860 responses and thereby a response ratio of 21.5 per cent. It was assumed that both sub-samples together represent a good cross-section of the population of communication professionals in Germany, whose size and structure are unknown. The average age of participants is 39 years. Descriptive and inferential statistical analysis was conducted using SPSS software (Wilcox, 2010). Even though it cannot be considered a representative study, it nevertheless provides good benchmark values. Based on the data from the survey, the status quo was analysed and future trends were identified.

In a second empirical stage of research, a qualitative Delphi study was conducted complementarily in June to July 2012. The trends identified earlier were presented in two subsequent waves to a panel of 32 academic and professional experts. Gläser und Laudel (2004, p. 10) define experts as persons with special knowledge about a certain matter and privileged access to information about that. For this research study, respondents were chosen on the basis of one of two criteria: either they academically publish about social media communication or are responsible for social media in an organisation that has been widely acknowledged for good social media activities (awards, prizes etc.) and that has been actively participating for more than two years. The experts were asked for evaluation and feedback on the developments and, in the second round, on the interpretations of their peers in the first wave. Delphi studies are dynamic, structured group surveys conducted in order to receive expert judgement on subjects with high level of uncertainty or little knowledge about them (Häder, 2002). The empirical method of Delphi studies in social sciences depicts a consensus of experts by interactively questioning them in numerous waves and presenting the results with more questions (Dalkey \& Helmer, 1963). Here, the method is expected to yield reliable forecasts on the future of social media communication. Apart than the quantitative summary of the most common responses, the Delphi method provided a qualitative approach, as the open questions and answers were analysed in detail to reveal more specific information. 


\section{Results}

Data from both stages of the study provide insights into the four research questions. As a multi-method approach was employed, the results are presented comparatively and combined.

\section{Combining centralised and decentralised cooperation}

Currently, 72.2 percent of the surveyed organisations actively use social media in their communication activities, while 20.3 percent plan to do so or use social media in the sense of passively monitoring the social media environment. In half of all organisations surveyed, there are now clearly defined responsibilities and cooperation structures for social media communication. Organisations with long-term social media experience or a large number of activities are even further advanced (statistically significant differences).

However, the collaboration styles within the organisations are described as very diverse, which suggests that the surveyed organisations try to find their own ways of handling this issue and do not follow one particular pattern. In almost one in three of the surveyed organisations, the communication professional state that internal collaboration regarding social media communication is rather spontaneous and experimental. Almost 19 percent claim that responsibilities for social media are not explicitly defined. A majority of the respondents state that their organisations employ ways of centrally controlled collaboration, while decentralised approaches are used almost as frequently. This indicates that collaboration is handled differently at various levels and often several organisational models are combined in the same organisation. One promising trend is the existence of specialised, interdisciplinary social media teams in 14.7 percent of all organisations. In a previous study one year before, only 11.5 percent of respondents affirmed having such a social media board or team (Fink et al., 2011) (see Figure 1).

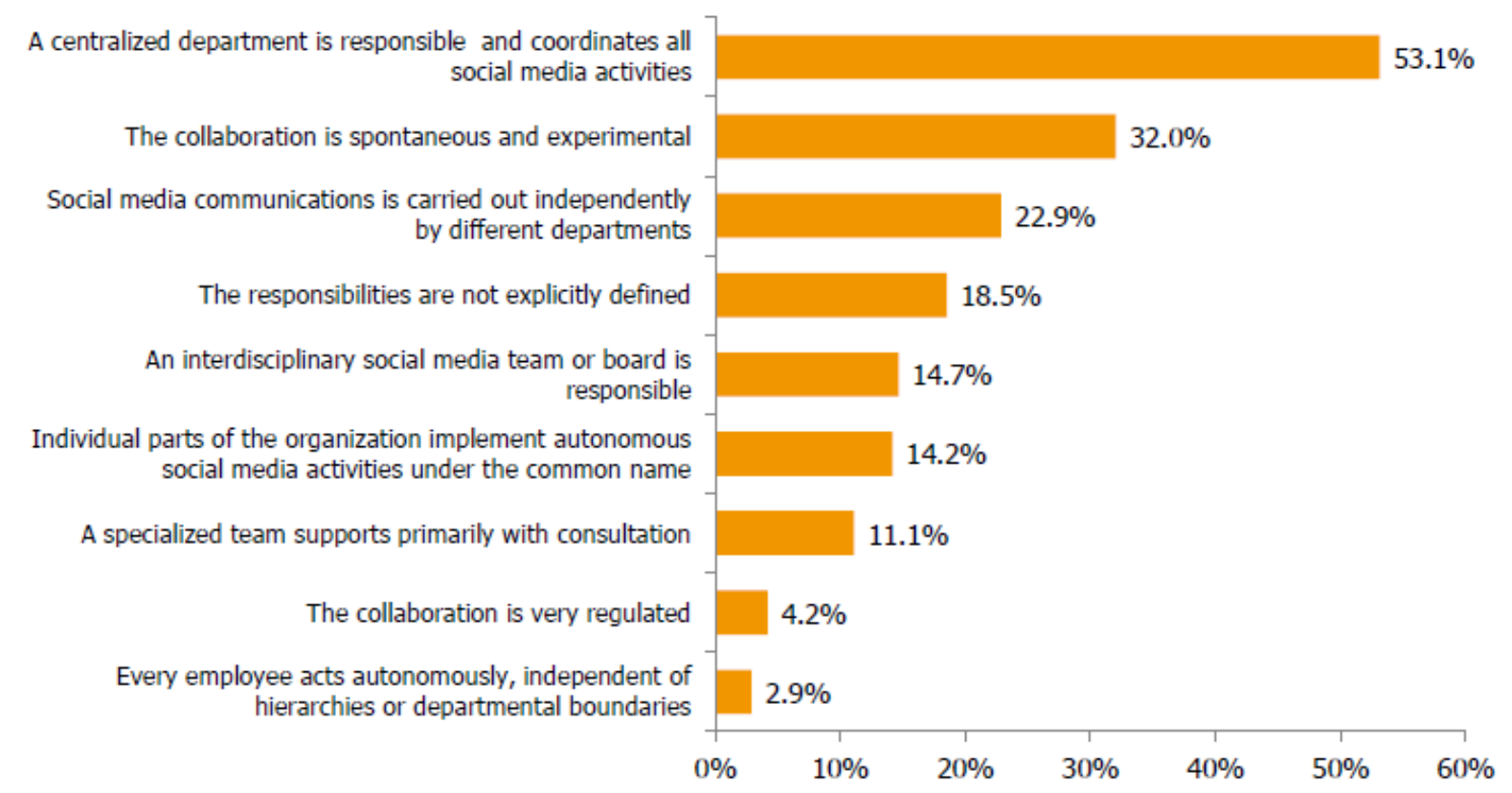

Figure 1. Current cooperation structures and responsibilities for social media ( $\mathrm{n}=621$ communication professionals in organisations that already utilize social media / Q 15: How does collaboration in social media activities take place in your organisation?)

When the Delphi panel was presented with the forecast that the now predominant, centralised approach will spread even further in future, dissent became apparent: 37.5 percent agreed, 31.2 percent disagreed, and roughly the same proportion was undecided. Similar differences 
occurred regarding the suitability of this approach. Clearly, the centralised model is associated equally with negative characteristics as it is with positive characteristics. Therefore, the experts' advice is to combine centralised expertise and decentralised communication. Typical statements made were: "There has to be a central person or team being responsible. Nonetheless, social media has to be integrated in nearly all business units. This has to be strategically coordinated by centralised experts." (Senior Manager Digital Engagement, global manufacturer of branded products) or "Governance, policy-making power and expertise (consultancy) is a job for a centralised expert, operational dialogue and implementation needs to be widely spread in the organisation." (Manager Online Communication, listed company). On the whole, the Delphi experts describe the integration into existing processes as a difficult task (59.4 percent agreement) (see Table 1).

\begin{tabular}{|c|c|c|c|c|c|}
\hline & \multicolumn{5}{|c|}{ Agreement on a scale from 1 to 5} \\
\hline & $\begin{array}{l}\text { 1(not at } \\
\text { all) }\end{array}$ & 2 & 3 & 4 & $\begin{array}{l}5 \text { (very } \\
\text { much) }\end{array}$ \\
\hline $\begin{array}{l}\text { How accurate do you think is the following forecast: The } \\
\text { centralised mode of social media communication will } \\
\text { spread even further in future? }\end{array}$ & $3.1 \%$ & $28.1 \%$ & $31.3 \%$ & $28.1 \%$ & $9.4 \%$ \\
\hline $\begin{array}{l}\text { How suitable do you find the centralised mode of social } \\
\text { media communication? }\end{array}$ & $6.3 \%$ & $25.0 \%$ & $34.4 \%$ & $28.1 \%$ & $6.3 \%$ \\
\hline $\begin{array}{l}\text { How easy is the integration of social media communication } \\
\text { into existing processes? }\end{array}$ & $6.3 \%$ & $53.1 \%$ & $40.6 \%$ & - & - \\
\hline
\end{tabular}

Table 1. Prediction regarding cooperation structures and responsibilities for social media (n = 32 experts; Delphi panel)

Questioned about the results from the first Delphi wave, all experts (aside from two undecided participants) advised using a combination of centralised and decentralised collaboration. Even though this procedure is not yet common in Germany, some organisations experiment with it and it can be assumed that it will spread further in future.

\section{Social media guidelines undergo changes and need acceptance}

In order to establish social media communication in organisations, more than just clear-cut responsibilities and cooperation procedures are needed. A supportive instrument often discussed is social media guidelines. The quantitative study shows that currently 39.1 percent of the surveyed organisations have implemented guides of this kind. This is a year-on-year increase of eight percentage points. On average, social media guidelines address seven different topics, the most frequently stated of these are "behavioural etiquette in social media” (11 percent of answers), “contact persons for social media activities” (9 percent), and the "separation of professional and private comments" (10 percent).

Guidelines are viewed as being important by 62.5 percent of the experts interviewed. One Delphi expert suggested that centralised experts create them as approximate outlines which can be altered for everyday work by decentralised communicators (Head of social media evaluation, measurement institute). The limits of regulation are well-known too: "Strategic outlines and guidelines should be created in a centralised manner, however business units and regional sub-organisations have to fill in those outlines individually" (Media researcher, university). Some experts talk about loss of control:

Social media is more than just another communication channel, it is a culture change. Every employee represents its enterprise via social media to external audiences and is connected to 
peers. This is a (conscious) loss of control to corporate communications, which needs to be dealt with - linking to training instead of control (Head of online communication, listed company).

Hence, one of the biggest challenges lies in balancing the necessary regulations with the flexibility typical for social media.

As with many other regulations, social media guidelines undergo different phases during their lifetimes. The development of guidelines is often described as complicated, as a balance needs to be found between necessary rules and freedom (Macnamara \& Zerfass 2012), while coordination with staff associations or legal departments is required. This is why guidelines undergo several developmental stages, which were reflected in the survey. Of the quantitavely surveyed organisations that have established guidelines, around 31 percent are in an early stage of planning and coordination, 49.9 percent have enforced guidelines, while 14.2 percent currently undertake a revision or have already revoked the guidelines. In the future, according to the Delphi experts, social media guidelines will be established by many more organisations. Some experts point out that, as with any change processes, guidelines need to be accepted by the people who are supposed to follow them. More than every second expert in the Delphi study suggests that employees should be involved when creating guidelines.

\section{Sporadic evaluation instead of integrated measurement systems}

As with any process of communication management, social media communication should be closed with an evaluation phase. Almost seven in ten survey respondents (66.6 per cent) state that they do not use any specific key performance indicators (KPIs) for measuring the success of social media activities at all. KPIs are only used more extensively by very active organisations and those who have long-term social media expertise (statistically significant differences). Among governmental agencies and NPOs substantially fewer KPIs are applied than in companies. The overall increase of eight percentage points over the previous year therefore should not hide the fact that there is still considerable room for improvement. Organisations that already evaluate their social media activities apply different methods: 79.4 percent can be categorised as applying sporadic and subjective evaluation, 12.8 percent use individual social media indicators and 7.8 percent apply an integrated social media measurement system.

Percentage of respondents

Specific social media evaluation systems will be widely established ...

$\begin{array}{cc}\text { until the end of } 2013 & 6.3 \% \\ \text { in } 1 \text { till } 3 \text { years } & 40.6 \% \\ \text { in } 4 \text { till } 6 \text { years } & 28.1 \% \\ \text { in } 7 \text { till } 9 \text { years } & 9.4 \% \\ & 15.6 \%\end{array}$

I don't even see it happening in the long-run.

Table 2. Prediction regarding the development of social media evaluation systems ( $\mathrm{n}=32$ experts / Delphi panel)

The relevance of systematic and specific social media evaluation is widely agreed upon by the Delphi experts (average agreement of 4.2 on a 5 point scale), but its implementation is considered difficult (average agreement of 3.9 on a 5 point scale). The following quote from the panel illustrates this: 
Major obstacles on an operational level are the non-existing standards of measurement. The lack of standardisation is mainly due to impossible enforceability by trade unions or enterprises and little economic payoff. Existing methods are relatively costly and in most organisations not backed up by a specific budget (Head of social media evaluation, measurement institute).

In the Delphi study, experts were asked their opinion about the forecast that this might improve within the next year, but only a minority agreed. A majority foresees improvements not earlier than within three years, as table 2 shows.

\section{Increasing social media governance and investments}

According to one Delphi panellist, organisations need to adapt their structures more frequently because the web constantly changes to new modes of communication and interactions (Web manager, global NPO). Indeed, an increase in governance structures for social media communication has been identified in the online survey: 55.5 percent report advanced structures. This is more than three times as many as two years ago (Fink \& Zerfass, 2010). Most widely spread are technical resources, supportive behaviour by the top management and freedom to communicate and react independently in the public sphere (see table 3). However, the positive trend that "the majority of all organisations will have a variety of specific rules and resources for social media communication by mid 2013" is not agreed upon by all experts in the Delphi study. On average, the experts are undecided with a tendency towards agreeing (average agreement of 4.34 on a five point scale). "Generally, one has to formulate clear aims and, based on that, define tasks. The Olympic idea of participation is not that important here, but, what the corporation wants to achieve. With these aims in mind, resources (time, money, personnel) can be asked for and justified” (Head of Corporate communications, global ITC enterprise). On the down side, the following challenges are named by the experts: lack of commitment to change, juxtaposing structures and processes, lack of competencies and understanding, and problems regarding the measurability of success.

\begin{tabular}{lccc}
\hline & Available & $\begin{array}{c}\text { Not } \\
\text { available }\end{array}$ & Not answered \\
\hline Technical possibility for accessing social media by staff during & $75.8 \%$ & $19.8 \%$ & $4.4 \%$ \\
working hours & $69.1 \%$ & $17.4 \%$ & $13.5 \%$ \\
$\begin{array}{l}\text { Support of social media by top management } \\
\text { The freedom to independently react and make decisions regarding }\end{array}$ & $62.8 \%$ & $26.9 \%$ & $10.3 \%$ \\
communication issues & & & \\
Defined responsibilities and cooperation structures for those & $49.9 \%$ & $43.0 \%$ & $7.1 \%$ \\
responsible for social media & $41.2 \%$ & $53.7 \%$ & $5.1 \%$ \\
Human resources for social media & $39.1 \%$ & $52.7 \%$ & $8.2 \%$ \\
Social media guidelines & $38.6 \%$ & $51.7 \%$ & $9.7 \%$ \\
Budgets/financial resources for social media & $35.5 \%$ & $54.9 \%$ & $9.6 \%$ \\
Monitoring tools for social media & $33.3 \%$ & $56.7 \%$ & $10.0 \%$ \\
Formulated targets or a strategy paper for social media & $33.1 \%$ & $59.7 \%$ & $7.2 \%$ \\
Social media workshops, seminars or training & $26.2 \%$ & $55.1 \%$ & $18.7 \%$ \\
Legal protection from potential risks and education of employees & & & $10.5 \%$ \\
about due courses of action & $22.9 \%$ & $66.6 \%$ & $10.5 \%$ \\
Key performance indicators for measuring the success of social media & & & \\
activities & &
\end{tabular}

Table 3. General conditions and governance structures for social media communication ( $\mathrm{n}=860$ Communication professionals / Q 7: Are the following general conditions for social media communication available in your organisation? Multiple answers possible) 
The expansion of social media structures and their integration into existing processes requires financial resources. The study reveals a positive trend in this regard: 38.6 percent of the surveyed communication professionals state that they have special budgets allocated to social media communication. This is a year-on-year increase of about 22 percentage points. Organisations with a longer experience in social media and a larger number of social media activities more often have a separate budget for social media (statistically significant differences). Similarly, larger companies and listed corporations are significantly better positioned in this regard. The majority of respondents (64 percent) expect this budget to increase in the future. NPOs and listed corporations expect the most improvements, while governmental institutions expect significantly fewer. Investments focus mainly on the creation and management of content (68.5 percent), as well as on developing communication concepts and overall strategies (54.2 percent) (see Figure 2).

The majority of respondents in the quantitative survey believe that the investments will increase further in future. The Delphi panel concurs. However, one expert offers a qualification: "I consider specific social media budgets as nonsense. Good communication units devote all their resources to different communication channels depending on the situational needs and can cater for relevant and contributing channels in the long-run” (Head of Corporate communications \& Marketing, service provider).

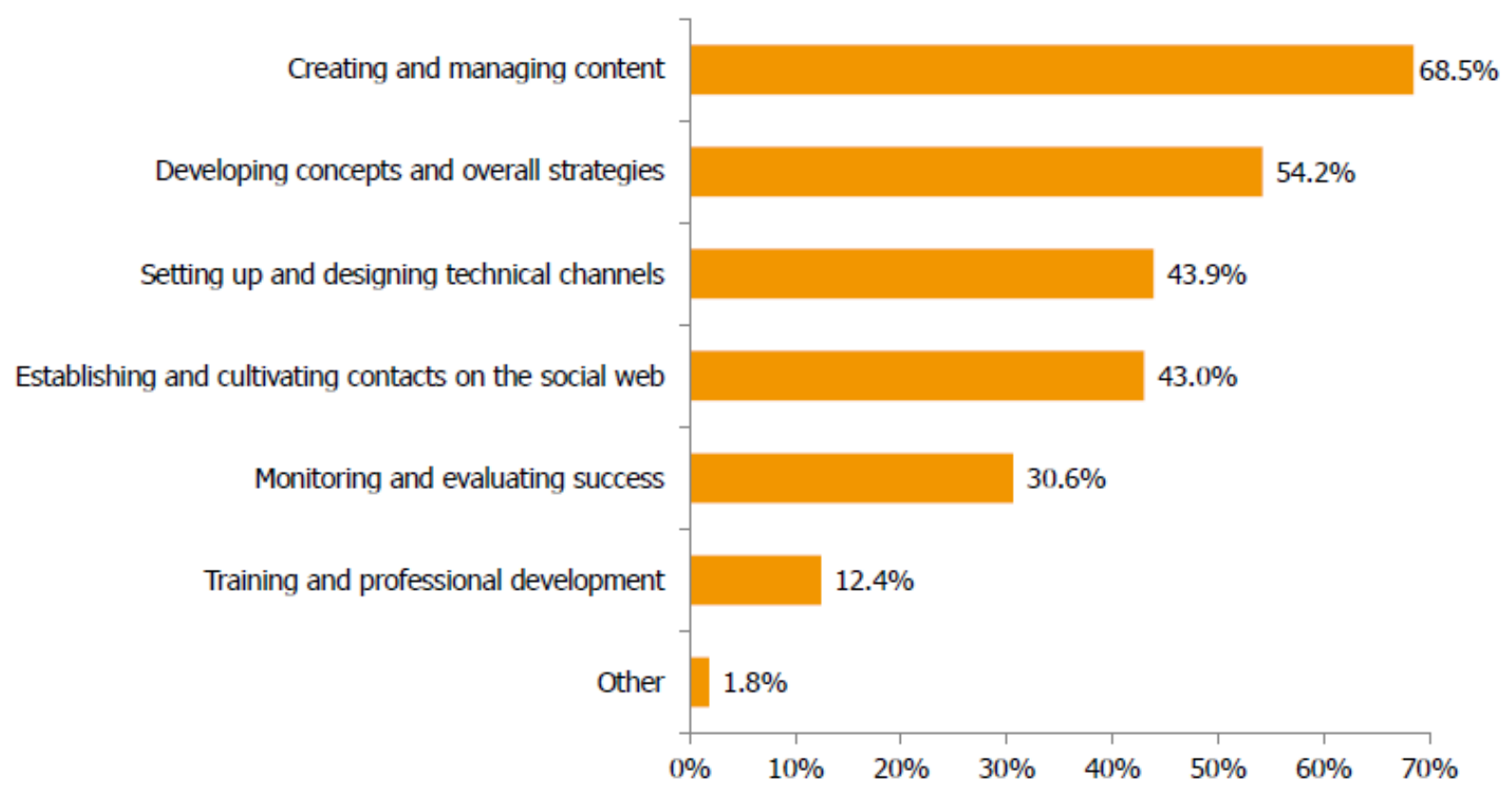

Figure 2. Focus of investments in social media communication

( $\mathrm{n}$ = 332 communication professionals in organisations with a specific social media budget / Q 10: In which aspects of social media does your organisation primarily invest? (Multiple answers possible) / Figure displays relative frequencies based on all answers)

\section{Conclusion}

\section{Interpretation and Discussion}

The multi method approach has provided useful means to conclude with some general tendencies in the field of social media communication and offers answers to the research questions: 
- Evolution from experimentation to social media governance: Despite many challenges, an ever increasing number of organisations establish the necessary and relevant structural conditions for social media communication. This will continue in future.

- Combination of decentralised und centralised responsibilities: Even though this coordination model is not predominant in Germany, many organisations experiment with it as it combines the advantages of both flexibility and strategic orientation. Experts consider the combination to be best suited for the practical challenges of social media. Therefore, it is predicted that this will prospectively be used by more organisations.

- Social media guidelines: Guidelines will be more widely adopted and implemented by organisations. In order to become relevant, the guidelines must be accepted by the members of those organisations. One possible way could be to include employees and members in the process of developing guidelines.

- Lack of evaluation: Valid and specific key performance indicators for social media are still missing or just being experimented with in most organisations. Improvements are expected within the next three years.

- Increasing investments in social media communication: Budgets for social media communication will rise in future. Mostly, resources will be allocated from other sources. However, the rationale for specific social media budgets is questioned by some experts as "Social media will be integrated increasingly into the everyday work of all communicators. In three years time it will no longer be standing alone but an integrated communication tool that everyone uses” (Social Media Manager, listed enterprise).

This study reveals that the advancement of German organisations from a first experimental phase to established structures is on its way. This general tendency (that is probably applicable to other countries) is nonetheless contrasted by many different and individual ways that organisations seek to improve their social media communication. Still existing shortcomings are "most likely a result of the relative newness of social media, the democratization of media and voice that they enable, and the changing nature of public and private spheres in a globalized, networked 'always on' world.” (Macnamara \& Zerfass, 2012, p. 303) The search for ways of dealing with this new communication environment as depicted in this study is also shown by other studies in Europe and Australasia (see e.g. Macnamara \& Zerfass, 2012). Of particular relevance is the availability of specific rules and resources, the so-called social media governance (Fink, Zerfass, \& Linke 2012). Here, major improvements are shown in this and other studies like the European Communication Monitor (Zerfass et al., 2012), and more improvements are expected by the Delphi experts.

\section{Limitations}

As this study was carried out in Germany, the results cannot be considered as being representative for other countries, e. g. those countries with different social media usage patterns. Although the general trends should not necessarily be doubted in their applicability to other regions, this needs to be further investigated. Some countries might be more advanced regarding the development of social media communication. Hence, future trends presented here might already be outdated in countries other than Germany. However, developments in other regions could tell a lot about future changes for the German communication landscape. Therefore, it would be especially interesting to draw a comparison. 
Experiments with different ways of integrating social media communication into existing procedures and cooperation processes within organisations are reported by the respondents of quantitative and qualitative aspects of the study. No clear picture of one best way is shown so far. This should be analysed in more detail, even with the help of other research methods. Content analysis would be especially suitable as it is less biased by social desirability than interviews such as those used in this research. This should be considered when interpreting the mentioned results.

The study reported here aligns with previous research in identifying improvements regarding social media communication. Nonetheless, developments seem to be slower than expected in earlier work. Results from this study could be used as reference points for upcoming research and for comparisons between forecasts and reality. This would help to make the dynamic and complex communication environment in the social web more understandable. Further insight into the integration of social media activities into existing processes and structures would fill a research gap and would help practitioners who struggle to integrate new technologies.

\section{References}

Argenti, P. A., \& Barnes, C. M. (2009). Digital Strategies for Powerful Corporate Communications. New York: McGraw-Hill.

Balnaves, M., Donald, S., \& Shoesmith, B. (2008). Media Theories and Approaches: A Global Perspective, Palgrave Macmillan.

Bauer, H. H. (2007). Interactive Marketing im Web 2.0+. Konzepte und Anwendungen für ein erfolgreiches Marketingmanagement im Internet [Interactive marketing in the Web 2.0]. München: Vahlen.

BITKOM (2012). Social Media in deutschen Unternehmen [Social media in German Enterprises]. Retrieved from: http://www.bitkom.org/files/documents/Social_Media_in_Unternehmen.pdf

Breakenridge, D. (2008). PR 2.0: New media, new tools, new audiences. Upper Saddle River, NJ: FT Press, Pearson Education.

Brown, J. S., \& Duguid, P. (2002). The Social Life of Information, Harvard Business Press.

Castells, M. (2010). The rise of the network society, $2^{\text {nd }}$ ed., Oxford: Wiley Blackwell.

Contractor, N. S., \& Eisenberg E. M. (1990). Communication networks and new media in organizations. In J. Fulk \& C. Steinfield (Eds.), Organizations \& Communication Technology (pp. 141-172). Newbury Park, CA: Sage.

Dalkey, N.C., \& Helmer, O. (1963). An experimental application of the Delphi method to the use of experts. Management science, 9(3), 458-467.

Diga, M., \& Kelleher, T. (2009). Social media use, perceptions of deicison-making power and public relations roles. Public Relations Review, 34(3), 440-442.

Döbler, T. (2008). Zum Einsatz von Social Software in Unternehmen [The application of social software in corporations]. In: C. Stegbauer \& M. Jäckel (Eds.), Social Software. Formen der Kooperation in computerbasierten Netzwerken [Social Software. Modes of Cooperation in Computer-Based Networks] (pp. 119-136). Wiesbaden: VS Verlag für Sozialwissenschaften.

Fink, S., \& Zerfass, A. (2010). Social media governance 2010. Results of a survey among communications professionals from companies, governmental institutions and nonprofit organizations in Germany. Leipzig, Wiesbaden: University of Leipzig, FFPR.

Fink, S., Zerfass, A. \& Linke, A. (2011). Social media governance 2011. Expertise Levels, Structures and Strategies of Companies, Governmental Institutions and Non-Profit 
Organizations communicating on the Social Web. Results of an empirical study of communications professionals. Leipzig/ Wiesbaden: University of Leipzig/FFPR.

Fink, S., Zerfaß, A., \& Linke, A. (2012). Social Media Governance. In A. Zerfaß \& T. Pleil (Eds.) (2012). Handbuch Online-PR. Strategische Kommunikation in Internet und Social Web [Handbook online public relations. Strategic communication on the internet and social web] (pp. 99-110). Konstanz: UVK.

Fraser, M., \& Dutta, S. (2008). Throwing sheep in the boardroom: How online social networking will transform your life, work and world. Chichester: John Wiley \& Sons.

Barnes, N. G., \& Mattson, E. (2009). Social media in the 2009 Inc. 500: New tools \& new trends. Retrieved from: http://davidanthonyporter.typepad.com/files/socialmedia2009.pdf

Gläser, J., \& Laudel, G. (2006). Experteninterviews und qualitative Inhaltsanalyse als Instrumente rekonstruierender Untersuchungen [Expert interviews and qualitative content analysis as instruments for reconstructive investigations]. VS Verlag, Wiesbaden.

Häder, M. (2002). Delphi-Befragungen, ein Arbeitsbuch [Delphi surveys, a handbook] Westdt. Verlag, Wiesbaden.

Hippner, H. (2006). Bedeutung, Anwendungen und Einsatzpotenziale von Social Software [Relevance, applications and potentials of social software]. HMD Praxis der Wirtschaftsinformatik, 43(252), 6-16.

Holtz, S., Havens, J. C., Johnson, L. D., \& International Association of Business Communicators (2008). Tactical transparency: How leaders can leverage social media to maximize value and build their brand. San Francisco, CA: Jossey-Bass.

Ihator, A. S. (2001). Communication style in the information age. Corporate Communications: An International Journal, 6(4), 199-205.

Jenkins, H. (2006). Convergence culture: Where old and new media collide. New York: New York University Press.

Kaplan, A. M., \& Haenlein, M. (2010). Users of the world, unite! The challenges and opportunities of Social Media. Business Horizons, 53(1), 59-68.

Lattemann, C., \& Stieglitz, S. (2007). Online Communities for Customer Relationship Management on Financial Stock Markets - A Case Study from a Project at the Berlin Stock Exchange. Proceedings of the 13th American Conference on Information Systems (AMCIS), Keystone, CO.

Li, C., \& Bernoff, J. (2008). Groundswell. Winning in a world transformed by social technologies. Boston, MA: Harvard Business School Press.

Luoma-aho, V., \& Vos, M. (2010). Towards a more dynamic stakeholder model: Acknowledging multiple issue arenas. Corporate Communications: An International Journal, 15(3), 315-331.

Macnamara, J. (2010a). The 21st century media (r)evolution : emergent communication practices. New York, Peter Lang.

Macnamara, J. (2010b). Public relations and the social: How practitioners are using, or abusing, social media. Asia Pacific Public Relations Journal, 11(1), 21-39.

Macnamara, J, \& Zerfass, A. (2012). Social media communication in organizations: The challenges of balancing openness, strategy and management. International Journal of Strategic Communication, 6(4), 287-308.

Nielsen (2012). STATE OF THE MEDIA: CONSUMER USAGE REPORT. Retrieved from: http://blog.nielsen.com/nielsenwire/mediauniverse/

Nightingale, V., \& Dwyer, T. (2007). New media worlds: challenges for convergence, Oxford University Press.

O'Reilly, T. (2005). What is Web 2.0? Design Patterns and Business Models for the Next Generation of Software. Retrieved from: http://www.oreilly.de/artikel/web20.html 
Owyang, J., \& Li, C. (2011). How Corporations Should Prioritize Social Business Budgets. Retrieved from: http://www.altimetergroup.com/research/reports/how-corporationsshould-prioritize-social-business-budgets

Pavlik, J. V. (2007). Mapping the Consequences of Technology on Public Relations. Retrieved from: http://www.instituteforpr.org/files/uploads/Pavlik_Mapping_Consequences.pdf

Pleil, T., \& Zerfass, A. (2007). Internet und Social Software in der Unternehmenskommunikation [Internet and social software in corporate communications]. In M. Piwinger \& A. Zerfass (Eds.), Handbuch Unternehmenskommunikation [Handbook of corporate communications] (pp. 511-534). Wiesbaden: Gabler.

Postman, J. (2009). SocialCorp: Social media goes corporate. Berkeley: New Riders. Ruisinger, D. (2007). Online Relations. Leitfaden für moderne PR im Netz [Online Relations. Guidelines for modern public relation on the web]. Stuttgart: Schäffer-Poeschel.

Safko, L. (2010). The Social Media Bible: Tactics, Tools, and Strategies for Business Success. Hoboken: John Wiley \& Sons.

Stankovic-Rice, B. L. (2011) Social media strategies to advance organizational change. Doctoral dissertation. Pepperdine University, Malibu, CA.

Toledano, M. (2010), Professional competition and cooperation in the digital age: A pilot study of New Zealand practitioners, Public Relations Review, 36 (3), 230-237.

Vaughan, E., \& Tinker, T. (2009). Effective Health Risk Communication About Pandemic Influenza for Vulnerable Populations. American Journal of Public Health, 99(2), 324332.

Wilcox, R. R. (2010). Fundamentals of modern statistical methods. Substantially improving power and accuracy. 2nd ed. New York: Springer.

Wright, D.K., \& Hinson, M.D. (2008). How blogs and social media are changing public relations and the way it is practiced. Public Relations Journal, 2(2), 1-21. Retrieved from: http://www.prsa.org/SearchResults/view/6D020203/0/How_Blogs_and_Social_Media_are_Changing_Public_Rel

Wright, D. K., \& Hinson, M. (2009). Examining how public relations practitioners actually are using social media. Public Relations Journal, 3(3). Retrieved from: http://www.prsa.org/Intelligence/PRJournal/Summer_09

Wright, D. K., \& Hinson, M. (2011). A Three-Year Longitudinal Analysis of Social and Emerging Media Use in Public Relations Practice. Public Relations Journal, 5(3). Retrieved from: http://www.prsa.org/intelligence/prjournal/documents/2011wrighthinson.pdf

Young, G. O., Brown, E. G., Keitt, T. J., Owyang, J. K., Koplowitz, R., \& Lo, H. (2008). Global Enterprise Web 2.0 Market Forecast: 2007 To 2013. Cambridge, USA: Forrester Research.

Zerfass, A. (2008). Corporate Communication Revisited: Integrating Business Strategy and Strategic Communication. In A. Zerfass, B. van Ruler \& K. Sriramesh (Eds.), Public Relations Research. European and International Perspectives and Innovations (pp. 6596). Wiesbaden: VS Verlag für Sozialwissenschaften.

Zerfass, A., Tench, R., Verhoeven, P., Vercic, D., \& Moreno, A. (2010). European Communication Monitor 2010. Status Quo and Challenges for Public Relations in Europe. Results of an Empirical Survey in 46 Countries. Brussels: EACD/EUPRERA, Helios Media.

Zerfass, A., Vercic, D., Verhoeven, P., Moreno, A., \& Tench, R. (2012). European Communication Monitor 2012. Challenges and Competencies for Strategic Communication. Results of an Empirical Survey in 42 Countries. Brussels: EACD/EUPRERA, Helios Media. 